\title{
Analisis Kandungan Gelatin Babi pada Masker Keluaran Korea yang Beredar Dipasaran Online Indonesia
}

\author{
Resi Andela ${ }^{1 *}$, Popi Rantina ${ }^{2}$, Anggra Pransiska ${ }^{3}$, Wan Zalya Fauziah ${ }^{4}$ Fahrul Anggara ${ }^{5}$ \\ ${ }^{1-4}$ Program Studi kimia Fakultas Sains dan Teknologi Universitas Islam Negeri Raden Fatah Palembang \\ ${ }^{5} \mathrm{PT}$. De Glow Internasional, Indonesia \\ *resiandela123@gmail.com
}

\begin{abstract}
ABSTRAK
Gelatin merupakan jenis protein yang diperoleh dari kolagen alami yang terdapat dalam kulit dan tulang babi dan sapi. Salah satu pemanfaatan gelatin adalah di bidang farmasi yaitu pembuatan masker wajah. Penelitian ini bertujuan untuk mengetahui kandungan gelatin dari masker produksi korea. Metode yang dilakukan dalam penelitian ini yaitu menggunakan spektrofometer FTIR. Hasil penelitian menunjukan bahwa sampel masker wajah produk korea tidak mengandung gelatin, terutama gelatin babi. Struktur gelatin pada umumnya memiliki gugus karbonil, amina, n-hidroksil, dimana pada Masker korea menunjukkan puncak serapan pada bilangan gelombang $3394,63 \mathrm{~cm}^{-1} ; 1637,68 \mathrm{~cm}^{-1}$; $1380,44 \mathrm{~cm}^{-1}$ dan $1460,94 \mathrm{~cm}^{-1}$. Hal ini menunjukkan masker ini mengandung gugus $\mathrm{OH}$ dari alkohol dan tidak mengandung gelatin karena serapan di daerah gugus fungsional $\left(3394,63 \mathrm{~cm}^{-1}\right)$ menunjukkan serapan yang kuat dan melebar. Dari hasil penelitian diperoleh bahwa dalam masker wajah produk korea ini tidak terdapat adanya kandungan gelatin sapi maupun gelatin babi.
\end{abstract}

Keywords: FTIR; Gelatin; Halal; Korea; Masker Wajah

\begin{abstract}
Gelatin is a type of protein obtained from natural collagen found in the skin and bones of pigs and cows. One of the uses of gelatin is in the pharmaceutical field which is making face masks. This study aims to determine the gelatin content of Korean mask production. The method used in this research is to use FTIR spectrophotometer. The results showed that the sample of Korean face masks did not contain gelatin, especially pork gelatin. In accordance with researchwhich states that the gelatin structure generally has carbonyl, amine, n-hydroxyl groups. Where in the Korean Mask shows the absorption peak at wave number $3394.63 \mathrm{~cm}-1$; $1637.68 \mathrm{~cm}-1 ; 1380.44 \mathrm{~cm}-1$ and $1460.94 \mathrm{~cm}-1$. This shows that this mask contains $\mathrm{OH}$ groups from alcohol and does not contain gelatin because the uptake in the functional group area $(3394.63 \mathrm{~cm}-1)$ shows a strong and wide absorption.
\end{abstract}

Keywords: FTIR; Gelatin; Halal; Korean; face mask.

\section{PENDAHULUAN}

Hanum (2013) menjelaskan bahwa kata cantik dan anggun itu identik sekali dengan perempuan. Hampir semua perempuan menginginkan paras yang cantik. Bagian tubuh yang paling diperhatikan adalah wajah. Semua 
perempuan percaya bahwa wajah merupakan cermin dari kecantikan. Banyak perempuan ingin memiliki kulit wajah yang bebas dari masalah kulit seperti jerawat, komedo dan kulit kering(Mahdiyyah \& Putriana, 2019). Pada saat ini wanita korea menjadi pusat kecantikan bagi semua wanita Asia terutama di Indonesia hal ini dikarenakan perempuan korea memiliki kulit yang putih, bersih dan sehat. Produk perawatan wajah yang digunakan perempuan korea mengandung bahan pemutih, karena mereka beranggapan kulit yang putih merupakan hal yang sangat penting untuk dikatakan cantik. Selain itu kepopuleran artis-artis korea pun sangat membantu akan terkenalnya produk kecantikan yang mereka gunakan, terutama masker wajah (Marliana et al., 2015).

Masker wajah merupakan bahan kecantikan yang sering digunakan oleh masyarakat dunia terutama masyarakat Indonesia dimulai dari kalangan remaja sampai dewasa. Biasanya masker yang digunakan oleh kalangan remaja sampai dewasa indonesia adalah masker wajah produksi korea hal ini dikarenakan banyaknya kalangan remaja sampai dewasa penggemar artis korea sehingga mereka akan mencoba apapun yang digunakan oleh idolnya. Karena kebanyakan masker yang digunakan produksi korea yang mayoritas masyarakatnya non-muslim membuat banyak peneliti ingin meneliti kandungan dari masker yang beredar terutama produksi korea (Miftahul, 2014).

Masker wajah adalah produk kecantikan yang sebagian besar digunakan oleh perempuan untuk membersihkan dan mengencangkan kulit. Masker wajah ini memiliki banyak bentuk seperti serbuk, pasta dan ada juga yang berbentuk gel. Masker wajah akan merangsang dan memperbaiki kulit, merangsang aliran darah maupun limpah. Masker wajah juga berfungsi membawa bahan-bahan aktif yang berguna bagi kesehatan kulit (Widyarti, Widodo., \& AF. Swaidatul, 2016). Masker wajah yang sering digunakan berbentuk gel atau pasta yang dioleskan pada wajah.

Gel merupakan sistem setengah padat yang terdiri dari suatu dispersi yang tersusun baik dari partikel anorganik yang kecil ataupun molekul organik yang besar terpenetrasi oleh suatu cairan (Nurjanah, Bintang Efrata, Andika, Mutiara, \& Tati, 2018). Masker berbentuk gel memiliki keuntungan diantaranya dapat langsung digunakan, memiliki kandungan air yang banyak sehingga dapat meredakan peradangan pada kulit, memberi kesan dingin saat menempel pada kulit. Biasanya masker wajah mengandung alkohol dan ada pula yang mengandung gelatin. Pada masker wajah produk korea kebanyakan mengandung alkohol dan gelatin, gelatin yang digunakan yaitu sapi dan babi. Bahan baku gelatin sendiri terdiri dari kulit sapi $28,7 \%$, kulit babi $41,4 \%$, serta kontribusi tulang sapi sebesar $29,8 \%$, dan sisanya dari ikan. Produksi gelatin dari bahan baku kulit babi $41 \%$, kulit sapi $28,6 \%$, tulang $30 \%$ dan porsi lainnya $0,4 \%$ (Swaidatul, Widodo, \& Sri, 2016).

Gelatin merupakan salah satu jenis protein yang diperoleh dari kolagen alami yang terdapat dalam kulit dan tulang. Gelatin ini banyak digunakan untuk keperluan industri baik industri pangan dan non pangan. DiIndonesia gelatin didapatkan dengan cara impor dari negara lain seperti negara Cina, Prancis, Selandia Baru, Jepang dan Australia. Gelatin babi didapatkan dari kulit babi $41,4 \%$, kulit sapi $28,7 \%$ dan tulang sapi sebanyak 29,8 \%, dan sisanya dari ikan (Muhammad, 2013).

Pada dasarnya gelatin dapat dibuat dari bahan apa saja yang mengandung kolagen yang tinggi seperti pada tulang dan kulit baik itu berasal dari sapi, babi maupun ikan dan bahkan bisa dari hewan lain yang memiliki kolagen yang tinggi (Musafar Hameed \& Abdullah, 2015). 
Namun kebanyakan gelatin yang beredar adalah gelatin babi hal ini dikarnakan faktor kesediaan dan kemudahan bahan baku serta efisiensi proses dan nilai ekonomis. Pada sapi dan hewan besar lainnya membutuhkan proses yang lebih lama dan memerlukan air pencuci atau penetrasi (bahan kimia) yang lebih banyak, dan biasanyanya mutunya lebih rendah dari gelatin kulit babi. walaupun memiliki mutu yang sama gelatin babi lebih mahal. Hal inilah yang menyebabkan gelatin babi lebih berkembang dari pada gelatin dari hewan lainnya(Istiqlaal, 2018).

Berdasarkan kondisi tersebut, maka dilakukan pengujian kandungan gelatin pada kosmetik, khususnya masker wajah menggunakan Spektofotometri FTIR. Hasil yang dimunculkan spektofotometri FTIR berupa sebuah spektra yang menginformasikan tentang gugus fungsi suatu senyawa yang terkandung didalam sampel (Astuti, 2016). Gugus fungsi suatu senyawa dapat terlihat dari bentuk dan panjang serapan yang muncul didaerah gugus fungsional dan daerah sidik jadi pada spektra (Dachriyanus, 2004).

\section{Pengujian ini dilakukan} berdasarkan kebutuhan masyarakat Indonesia khususnya kaum perempuan dalam bidang kecantikan. Karena seperti yang kita ketahui bahwa penduduk Indonesia mayoritas beragama islam. Maka dari itu perlu dilakukan pengujian kehalalan dari suatu produk, baik itu pakaian, makanan, maupun produk kosmetik. Untuk itu diharapkan setiap produk yang di impor ke Indonesia sudah terjamin kehalalan nya.

\section{METODOLOGI PENELITIAN}

\section{Alat dan Bahan}

Adapun alat yang digunakan dalam penelitian ini adalah pipet tetes, cawan petri, gelas kimia, dan instrumen
Spektofotometri FTIR.

Adapun bahan-bahan yang digunakan dalam penelitian ini adalah masker yang didapat dari pembelian secara online, dan etanol. Analisis gelatin Dengan FTIR 13.000- ${ }^{10}$ dengan melibatkan pengontrol kerja berupa personal computer yang dilengkapi perangkat lunak OPUS versi 7.5.

\section{HASIL DAN PEMBAHASAN}

Pembuatan Masker wajah dapat dihasilkan dari bahan-bahan alam yang sangat berguna untuk mengurangi keriput pada wajah. Bahan-bahan alami yang digunakan sebagai pembuatan masker tersebut harus mengandung vitamin $\mathrm{A}, \mathrm{C}$, $\mathrm{E}$, dan zinc sehingga nantinya diharapkan mampu mengurangi keriput pada wajah. Vitamin-vitamin tersebut dapat diperoleh dari gelatin, bengkoang, minyak jintan hitam, dan cokelat, sebagai bahan dasar masker mengandung vitamin $\mathrm{C}$ yang berfungsi untuk pembentukan kolagen dan proses pigmentasi, vitamin $\mathrm{C}$ dapat diabsorpsi oleh kulit (Ayuthia Hairina \& Swaidatul, 2017).

Masker berbentuk gel memiliki keuntungan diantaranya dapat langsung digunakan, memiliki kandungan air yang banyak sehingga dapat meredakan peradangan pada kulit, memberi kesan dingin saat menempel pada kulit. Biasanya masker wajah mengandung alkohol dan ada pula yang mengandung gelatin.

Muhammad (2013) melaporkan bahwa struktur gelatin pada umumnya protein memiliki gugus karbonil, amina, nhidroksil. Gelatin memunculkan serapan IR khas amida A pada bilangan gelombang 3600-2300 $\mathrm{cm}^{-1}$, amida I pada 1636-1661 $\mathrm{cm}^{-1}$, amida II pada 1560 $1335 \mathrm{~cm}^{-1}$, dan amida III pada $1300-1200$ $\mathrm{cm}^{-1}$. Gelatin sapi hasil isolasi, standar gelatin sapi babi munculkan puncak serapan amida A berturut-turut pada 
bilangan gelombang 38.98, 3649.99, dan $3649.99 \mathrm{~cm}^{-1}$. Gugus amida I juga terlihat pada bilangan gelombang berturut-turut 1651.25, 1652.12, dan $1651.44 \mathrm{~cm}^{-1}$. Daerah amida II dan III masih terlihat jelas pada spektrum IR gelatin sapi dengan panjang 1454.13 dan $1245.07 \mathrm{~cm}^{-}$

1. Pada standar gelatin sapi dan babi, kedua puncak serapan tersebut tidak begitu tajam, terutama untuk amida III (Gambar

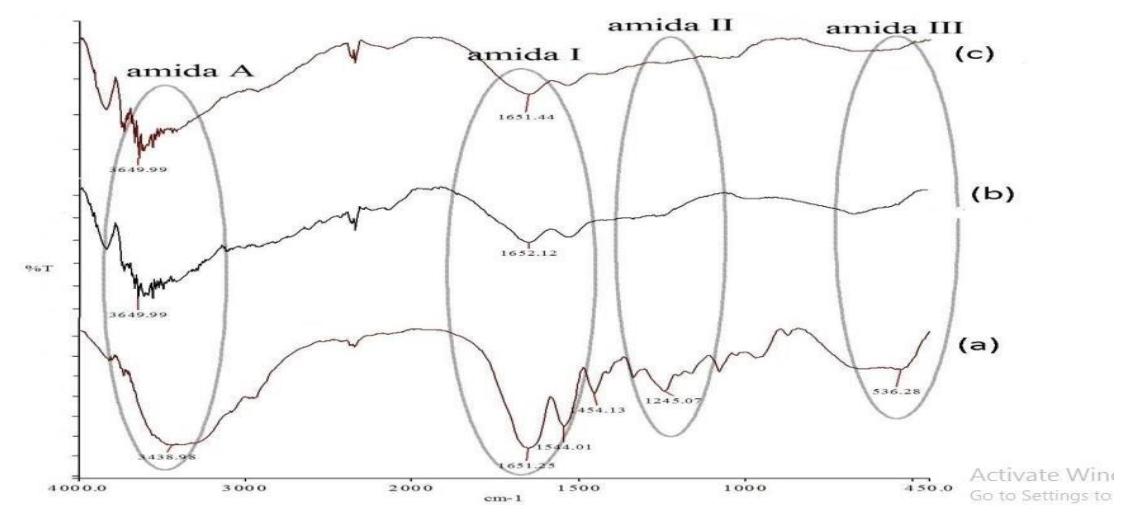

Gambar.1 Spektrum FTIR gelatin sapi (a), standar gelatin sapi (b), dan standar gelatin babi (c) (Muhammad, 2013)

Gambar 1 menunjukan serapan yang mucul pada gelatin sapi dan babi. Daerah serapan amida A ditimbulkan oleh vibrasi regangan $\mathrm{OH}$ dan $\mathrm{NH}$, untuk puncak yang melebar menunjukkan keberadaan gugus $\mathrm{OH}$ dari asam hidroksiprolina. Puncak serapan pada daerah amida I menunjukkan residu amida dan struktur gulungan acak pada gelatin. Puncak serapan daerah amida II menunjukkan struktur rantai $\alpha$ berpilin dan asam amino. Puncak pada daerah serapan amida III berasal dari struktur unting ganda agen pada gelatin sapi. Hal ini menunjukkan bahwa masih ada kolagen yang belum terhidrolisis menjadi struktur unting tunggal. Standar sapi dan babi hampir tidak memiliki puncak pada daerah amida III.

Hasil analisa masker korea pada penelitian ini, memunculkan puncak serapan pada bilangan gelombang $3394,63 \mathrm{~cm}^{-1} ; 1637,68 \mathrm{~cm}^{-1} ; 1380,44 \mathrm{~cm}^{-1}$ dan $1460,94 \mathrm{~cm}^{-1}$ (Gambar 2).

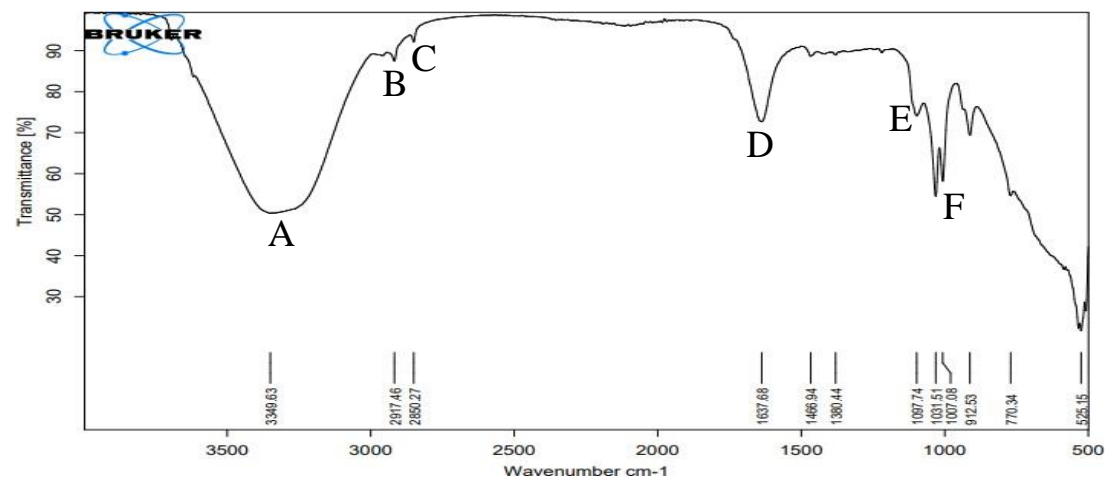

Gambar.2 Spektrum FTIR masker korea 
Berdasarkan Gambar 2, daerah serapan A memiliki puncak yang melebar. Hal ini menunjukkan adanya gugus $\mathrm{OH}$ dari alkohol, hal ini juga didukung dengan adanya serapan C-O didekat serapan E.

Daerah serapan D menunjukkan adanya ikatan $\mathrm{C}=\mathrm{C}$ yang merupakan rantai alifatik karena memiliki serapan di daerah kanan $3000 \mathrm{~cm}^{-1}$. Tidak adanya serapan pada daerah 1820-1600 $\mathrm{cm}^{-1}$ menunjukkan tidak adanya gugus karbonil, dan puncak yang melebar pada daerah serapan A menunjukkan adanya gugus alkohol bukan amida. Dengan tidak adanya kedua gugus utama yang mencirikan keberadaan gelatin, maka sampel masker produk korea ini tidak menggunakan gelatin. Jadi masker yang digunakan negatif mengandung gelatin babi.

\section{KESIMPULAN}

Dari hasil penelitian diperoleh bahwa dalam masker wajah produk korea ini tidak terdapat adanya kandungan gelatin sapi maupun gelatin babi. Terlihat pada daerah serapan pada bilangan gelombang $3394,63 \mathrm{~cm}^{-1}$ memiliki puncak yang melebar ini menunjukkan adanya gugus $\mathrm{OH}$ dari alkohol.

\section{DAFTAR PUSTAKA}

Astuti, A. (2016). Determinasi Dan Analisis Finger Print Daun Miana ( Coleus Scutellarioides Linn . ) Sebagai Bahan Baku Obat Tradisional Dengan Metode Spektroskopi Ft-Ir Dan Kemometrik. 4(2), 58-64.

Ayuthia Hairina, A., \& Swaidatul, M. A. (2017). Formulasi Masker Alami Berbahan Dasar Rumput Laut Dan Cokelat Mengurangi Keriput Dan Bintik Noda Pada Kulit Wajah. Jurnal Care, 5(2), 205-219.
Dachriyanus. (2004). Analisis Struktur Senyawa Organik Secara Spektroskopi. Padang: Lembaga Pengembangan Teknologi Infomasi dan Komunikasi LPTIK.

Istiqlaal, S. (2018). Characteristics of Gelatin Produced Immersion of Tuna Bone in Lontar Vinegar from East Nusa Tenggara. Jurnal Pengolahan Hasil Perikanan Indonesia, 21(3), 443. https://doi.org/10.17844/jphpi.v21i3.2 4716

Mahdiyyah, M., \& Putriana, N. A. (2019). Analisis Kimia untuk Mendeteksi Kandungan Non-Halal pada Kosmetik. Farmasetika.Com (Online), 4(5), 155164.

https://doi.org/10.24198/farmasetika.v 4 i5.23067

Marliana, A., Syaripah Nazirah, S. A., Nor Adha, A. H., Norazla, A. H., Wawarah, S., Surianom, M., ... Norziah, O. (2015). WAR 26 the challenges of islamic trade finance in promoting SMEs for halal industry in Malaysia. Isu Dan Cabaran Pensijilan Halal: Satu Kajian Perbandingan Antara Malaysia Dan Thailand, 2015(December), 92-110.

Miftahul, J. (2014). Gambaran Identitas Diri Remaja Akhir Wanita Yang Memiliki Fanatisme K-Pop Di Samarinda. Gambaran Identitas Diri Remaja Akhir Wanita Yang Memiliki Fanatisme K-Pop Di Samarinda, 2(2), 182-194. Retrieved from ejournal.ip.fisip-unmul.org

Muhammad, R. (2013). Identifikasi Dan Pencirian Fisikokimia Gelatin. Bogor: INSTITUT PERTANIAN BOGOR.

Musafar Hameed, L. B., \& Abdullah, M. (2015). World Academic and Research Congress 2015 (World-AR 2015) ArRahim Hall, YARSI University, 
Jakarta, Indonesia, 9th - 10th December 2015. World Acedemic and Research Congress, 2015(December), 207-214.

Nurjanah, Bintang Efrata, A., Andika, F., Mutiara, R., \& Tati, N. (2018). Senyawa Bioaktif Rumput Laut Dan Ampas Teh Sebagai Antibakteri Dalam Formula Masker Wajah. 21, 304-316.

Swaidatul, M. A., Widodo, \& Sri, W. (2016). Formulasi Masker Alami Berbahan Dasar Bengkoang Dan Jintan Hitam Untuk Mengurangi Kerutan Pada Kulit Wajah. Jurnal Care, 4(2), 22-35.

Widyarti, S., Widodo., \& AF. Swaidatul, M. (2016). Formulasi Masker Alami Berbahan Dasar Bengkoang dan Jintan Hitam untuk Mengurangi Kerutan pada Kulit Wajah. Jurnal Care, 4(3), 9-20. 